\title{
Evaluation of Soybean Cultivars of Contrasting Cycles according to the Level of Investment in Fertilization
}

\author{
Emerson Borghi'1, Eduardo de Paula Simão², Álvaro Vilela de Resende1, \\ João Carlos Cardoso Galvão², Sebastião Pedro da Silva Neto ${ }^{3}$, André Ferreira Pereira ${ }^{3}$ \\ ${ }^{1}$ Embrapa Maize and Sorghum, SeteLagoas, Brazil \\ ${ }^{2}$ Department of Plant Science, Federal University of Viçosa, Viçosa, Brazil \\ ${ }^{3}$ EmbrapaCerrados, Planaltina, Brazil \\ Email: emerson.borghi@embrapa.br, eduardosimao.agro@yahoo.com.br, alvaro.resende@embrapa.br, \\ jgalvao@ufv.br, sebastiao.pedro@embrapa.br, andre.ferreira@embrapa.br
}

How to cite this paper: Borghi, E., de Paula Simão, E., de Resende, Á.V., Galvão, J.C.C., da Silva Neto, S.P. and Pereira, A.F. (2017) Evaluation of Soybean Cultivars of Contrasting Cycles according to the Level of Investment in Fertilization. American Journal of Plant Sciences, 8, 2977-2994. https://doi.org/10.4236/ajps.2017.812202

Received: October 6, 2017

Accepted: November 10, 2017

Published: November 13, 2017

Copyright $\odot 2017$ by authors and Scientific Research Publishing Inc. This work is licensed under the Creative Commons Attribution International License (CC BY 4.0).

http://creativecommons.org/licenses/by/4.0/

\begin{abstract}
The objective of the present study was to characterize the duration of the phenological stages, the agronomic characteristics and grain yield in soybean cultivars with contrasting cycles and indeterminate growth type, submitted to different fertilization investment environments under no-tillage system in the central region of Minas Gerais. The work was conducted under field conditions, in an experimental area of Embrapa Maize and Sorghum, in Sete Lagoas, MG, in the harvest of 2015/2016. Ten soybean cultivars with different relative maturity groups (RMG) were studied, representing almost all RMG materials currently sown in Minas Gerais, in two environments with different levels of fertilizer investment. The variables were submitted to analysis of joint variance, in order to verify the existence of interaction between cultivars and investment in fertilization environments. Fertilizer investment levels influence grain yield of soybean cultivars of contrasting cycles. The higher height of the soybean plants implies higher lodging and lower grain yield. This situation is aggravated by the greater investment in fertilization. The difference between the cycles of the cultivars is in the duration of the vegetative stages, being greater in the later cultivars.
\end{abstract}

\section{Keywords}

Glycine max L. (Merrill), Growth Habit, Relative Maturity Group

\section{Introduction}

Among all grain crops in the state of Minas Gerais, soybean accounted for $44 \%$ 
of the cultivated area and $37 \%$ of the total volume of grains produced in the 2015/2016 crop, according to the National Supply Company [1].

According to Alliprandini et al. [2], the State of Minas Gerais is in the region corresponding to the relative maturity group (RMG) between 7 and 8. According to the authors, the relative maturity group of each cultivar, according to the American system of classification allows the producer to obtain more assertive information for the decision per cycle of the cultivars, besides the productive potential and the other agronomic characteristics.

Due to the fact that the state of Minas Gerais is north of the $24 \mathrm{~S}$ parallel, the State presents climatic adversities, and each year, the periods of water restriction or even irregular distribution of rainfall over the year become more imminent, associated with temperatures which may compromise the good development of soybean cultivation in the state [3].

The environment exerts a great influence on the behavior of soybean cultivars. This is especially true because of soil fertility, water availability, temperature, luminosity and occurrence of diseases, as well as the degree of lodging and productivity [4]. In order to try to find materials that are more resistant to regional adversities, the breeding programs have been working on early-cycle cultivars of indeterminate growth type and herbicide and pest tolerance genes. Zanon et al. [5] reported that, in southern Brazil, this new group of cultivars represented more than $90 \%$ of the area planted with soybeans in the last 5 years, allowing greater flexibility in early sowing (September) or when this season can extend to January. According to the Biotechnology Information Council [6], the growth rates of transgenic crops in Brazil in 2014 were $94.2 \%$ of soybean cultivated area, $84.6 \%$ for corn and $73.3 \%$ for cotton.

Plant productivity is determined by physiological, genetic, as well as biotic to abiotic factors [7]. According to Evans et al. [8], potential productivity is defined as the maximum production of seeds (or dry matter) of a cultivar in a given environment, having available water and nutrients according to their phenological needs and absence of factors that can cause their disorders. For Ribeiro et al. [9], the definition of soybean grain productivity is based on the interaction between plant, production environment and the management adopted, besides considering the high adaptability of the genotype and the productive potential for a given region. All these factors interact with the cultivation system and the management required by soybean in function of its development. Thus, studies that promote the characterization function in cultivars of different regional characteristics are extremely important since such information helps in decision making on the choice of material depending on the employee's level of investment and provides important information such as setting the time planting, selection of varieties depending on the degree of relative maturity, seeding and other management practices to explore the maximum genetic potential of each cultivar [5].

Given the lack of positioning data of modern soybean cultivars in the central region of Minas Gerais, the present study aimed to characterize the duration of 
phenological stages, agronomic characteristics and grain yield in soybean cultivars with contrasting cycles, submitted to different fertilization investment environments under no-tillage system.

\section{Material and Methods}

The experiment was conducted during the 2015/2016 harvest, under field conditions, at Embrapa Maize and Sorghum, in SeteLagoas-MG, with coordinates of $19^{\circ} 28^{\prime} 30^{\prime \prime} \mathrm{S}, 44^{\circ} 15^{\prime} 08^{\prime \prime} \mathrm{W}$ and $732 \mathrm{~m}$ of altitude. The soil was characterized as a very clayey dystroferric Red Latosol [10]. The climatic classification of the region according to Köppen is type Aw, typical of savannah, with dry winter and average temperature of the air of the coldest month superior to $18^{\circ} \mathrm{C}$.

The experimental area has been established in a no-tillage system for eight years, with crops mainly soybean and corn. In 2012, the area was divided into two conditioned environments under medium or high technological investment in fertilization [11] and since then it has been maintained with different fertilization in each environment. In the off-season of 2013, millet + crotalaria were planted as cover plants in both environments, followed by maize cultivation in the summer (average grain yield of $8780 \mathrm{~kg} \cdot \mathrm{ha}^{-1}$ for the medium-investment environment and $9945 \mathrm{~kg} \cdot \mathrm{ha}^{-1}$ for the high-investment environment), and beans (average grain yield of $1464 \mathrm{~kg} \cdot \mathrm{ha}^{-1}$ for the medium-investment environment and $1747 \mathrm{~kg} \cdot \mathrm{ha}^{-1}$ for the high-investment environment) were grown in the 2014 off-season. In the 2014/2015 crop, summer maize (mean grain yield of 10744 $\mathrm{kg} \cdot \mathrm{ha}^{-1}$ for the medium-investment environment and 11,304 kg.ha ${ }^{-1}$ for the high-investment environment) was cultivated and, after grain harvest, the seeding of forage turnip in total area.

Table 1 shows the maximum, minimum and rainfall data collected in the climatological station located at Embrapa Maize and Sorghum during the period of conduction of the experiment, as well as the average of the last 50 years.

Table 1. Maximum temperature, minimum and precipitation Sete Lagoas-MG, during the experiment driving time and average of the last 50 years.

\begin{tabular}{cccccccc}
\hline \multirow{2}{*}{ Climatic feature } & October & November & December & January & February & March & April \\
\cline { 2 - 7 } & \multicolumn{7}{c}{ 2015/16 Crop } \\
\hline T.max $\left(\mathrm{C}^{\circ}\right)$ & 34.9 & 32.3 & 31.6 & 32.2 & 33.5 & 31.1 & 29.6 \\
T.min $\left(\mathrm{C}^{\circ}\right)$ & 18.3 & 19.0 & 18.1 & 19.5 & 18.9 & 18.5 & 18.3 \\
Rain $(\mathrm{mm})$ & 125.5 & 117.7 & 215.8 & 364.5 & 55.6 & 117.4 & 40.6 \\
& & & & & & & \\
T.max $\left(\mathrm{C}^{\circ}\right)$ & 29.7 & 28.8 & 28.7 & 29.5 & 30.0 & 29.6 & 28.6 \\
T.min $\left(\mathrm{C}^{\circ}\right)$ & 17.4 & 18.1 & 18.5 & 18.6 & 18.5 & 18.3 & 16.7 \\
Rain $(\mathrm{mm})$ & 100.1 & 220.4 & 287.1 & 270.7 & 156.7 & 160.0 & 59.6 \\
\hline
\end{tabular}

T. $\max \left(\mathrm{C}^{\circ}\right)$-Average maximum temperature in degrees Celsius and T. min $\left(\mathrm{C}^{\circ}\right)$-Average minimum temperature in degrees Celsius. 
Before the sowing of the experiment, in November of 2015, soil sampling was performed at depths of 0 to $20 \mathrm{~cm}$ depth in both environments, whose chemical attributes are: in the environment of medium investment were: $\mathrm{pH}$ in water 6.1; organic matter 3.8 dag. $\mathrm{kg}^{-1} ; \mathrm{P}$ and $\mathrm{K}$ (Mehlich 1) contents of 11.5 and 13.5 $\mathrm{mg} \cdot \mathrm{dm}^{-3}$, respectively; $\mathrm{Ca}, \mathrm{Mg}, \mathrm{Al}, \mathrm{H}+\mathrm{Al}$ and potential CTC of $4.0 ; 0.8 ; 0.1 ; 5.3$; $10 \mathrm{cmolc} \cdot \mathrm{dm}^{-3}$, respectively; base saturation (V\%) of 47.8; Saturation by $\mathrm{Al}(\mathrm{m} \%)$ of 1.4 ; and contents of $\mathrm{Cu}, \mathrm{Fe}, \mathrm{Mn}, \mathrm{Zn}$ of $0.7 ; 29.0 ; 24.8 ; 1.4 \mathrm{mg} \cdot \mathrm{dm}^{-3}$, respectively. In the high investment environment where: $\mathrm{pH}$ in water 6.0; organic matter $3.9 \mathrm{dag} \cdot \mathrm{kg}^{-1}$; $\mathrm{P}$ and $\mathrm{K}$ (Mehlich 1) contents of 19.7 and $54.4 \mathrm{mg} \cdot \mathrm{dm}^{-3}$, respectively; $\mathrm{Ca}, \mathrm{Mg}, \mathrm{Al}, \mathrm{H}+\mathrm{Al}$ and potential CTC of $3.6 ; 0.9 ; 0.0 ; 6.3 ; 10.9 \mathrm{cmolc}^{\mathrm{dm}}{ }^{-3}$, respectively; base saturation $(\mathrm{V} \%)$ of 42.8 ; Saturation by $\mathrm{Al}(\mathrm{m} \%)$ of 0.8 ; and contents of $\mathrm{Cu}, \mathrm{Fe}, \mathrm{Mn}, \mathrm{Zn}$ of $0.7 ; 26.1 ; 243.6 ; 1.4 \mathrm{mg} \cdot \mathrm{dm}^{-3}$, respectively. The granulometric analysis was detected: sand $=130 \mathrm{~g} \cdot \mathrm{kg}^{-1} ;$ silt $=210 \mathrm{~g} \cdot \mathrm{kg}^{-1}$; clay $=$ $660 \mathrm{~g} \cdot \mathrm{kg}^{-1}$.

The experiment consisted of the cultivation of ten soybean cultivars in medium and high fertilization environments, whose transgenic technologies and agronomic characteristics informed by the companies that own the seeds are presented in Table 2. The cultivars used in the experiment were selected by different groups of relative maturity (RMG), which represent almost all the material with RMG currently sown in Minas Gerais.

For each environment, the experimental design was in randomized blocks with four replicates, each experimental unit consisting of eight lines of $7 \mathrm{~m}$ in length, spaced $0.5 \mathrm{~m}$ apart. As a useful area for the evaluations the four central lines were considered, discarding a meter at the edges as border.

In November of 2015, the vegetation cover of the area was desiccated by applying the glyphosate herbicide (1800 g.ha ${ }^{-1}$ of a.i.) + Triazolone (30 g.ha ${ }^{-1}$ of a.i.) to the total area, with $250 \mathrm{~L} \cdot \mathrm{ha}^{-1}$. The sowing occurred on December 14 , 2015 with the use of no-till fertilizer for no-till, with 4 rows spaced $0.50 \mathrm{~cm}$.

Table 2. Soybean cultivars, relative maturity groups (RMG), growth habit, cycle and recommended plant stand of the materials evaluated in the experiment.

\begin{tabular}{ccccc}
\hline Cultivar & RMG & Growth habit & Cycle (days) & Booth (thousandplants ha $^{-1}$ ) \\
\hline ST 797 & 7.9 & Undetermined & 125 & 300 \\
M 6410 & 6.4 & Undetermined & 142 & 320 \\
M 6210 & 6.2 & Undetermined & 112 & 360 \\
Flecha & 6.6 & Undetermined & 110 & 320 \\
NS 7300 & 7.3 & Undetermined & 130 & 320 \\
PP 7500 & 7.5 & Undetermined & 120 & 300 \\
TMG 2158 & 5.8 & Undetermined & 105 & 370 \\
RK 5813 & 5.8 & Undetermined & 100 & 380 \\
BRS 7780 & 7.7 & Determined & 115 & 300 \\
BRS 8180 & 8.1 & Undetermined & 125 & 300 \\
\hline
\end{tabular}


Regardless of the cultivar and of the fertilization investment environment, seed regulation was estimated to produce 300,000 plants per hectare. All cultivars were inoculated with Bradyrhizobium japonicum.

For the medium-investment environment, sowing fertilization consisted of the application in the line of $7 \mathrm{~kg} \cdot \mathrm{ha}^{-1}$ of $\mathrm{N}, 71 \mathrm{~kg} \cdot \mathrm{ha}^{-1}$ of $\mathrm{P}_{2} \mathrm{O}_{5}, 71 \mathrm{~kg} \cdot \mathrm{ha}^{-1}$ of $\mathrm{K}_{2} \mathrm{O}$, $27.1 \mathrm{~kg} \cdot \mathrm{ha}^{-1}$ of $\mathrm{Ca}, 12.7 \mathrm{~kg} \cdot \mathrm{ha}^{-1}$ of S, $177.0 \mathrm{~g} \cdot \mathrm{ha}^{-1}$ of B, $212.4 \mathrm{~g} \cdot \mathrm{ha}^{-1}$ of Mn and $955.8 \mathrm{~g} \cdot \mathrm{ha}^{-1}$ of $\mathrm{Zn}$, corresponding to $354 \mathrm{~kg} \cdot \mathrm{ha}^{-1}$ of formulated fertilizer $02-20-20$ $+7.66 \% \mathrm{Ca}+3.6 \% \mathrm{~S}+0.05 \% \mathrm{~B}+0.06 \% \mathrm{Mn}+0.27 \% \mathrm{Zn}$.

For the high-investment environment, sowing fertilization consisted of the application of $11.24 \mathrm{~kg} \cdot \mathrm{ha}^{-1}$ of $\mathrm{N}, 112 \mathrm{~kg} \cdot \mathrm{ha}^{-1}$ of $\mathrm{P}_{2} \mathrm{O}_{5}, 112 \mathrm{~kg} \cdot \mathrm{ha}^{-1}$ of $\mathrm{K}_{2} \mathrm{O}, 43.0$ $\mathrm{kg} \cdot \mathrm{ha}^{-1}$ of Ca, $20.2 \mathrm{~kg} \cdot \mathrm{ha}^{-1}$ of S, $281.0 \mathrm{~g} \cdot \mathrm{ha}^{-1}$ of B, $337.2 \mathrm{~g} \cdot \mathrm{ha}^{-1}$ of Mn and 1517.4 $\mathrm{g} \cdot \mathrm{ha}^{-1}$ of $\mathrm{Zn}$, corresponding to $562 \mathrm{~kg} \cdot \mathrm{ha}^{-1}$ of the formulated fertilizer $02-20-20+$ $7.66 \% \mathrm{Ca}+3.6 \% \mathrm{~S}+0.05 \% \mathrm{~B}+0.06 \% \mathrm{Mn}+0.27 \% \mathrm{Zn}$.

Immediately after sowing, still in pre-emergence of soybean, it was applied in total herbicide paraquate $\left(600 \mathrm{~g} \cdot \mathrm{ha}^{-1}\right.$ of a.i.) to control the remaining weeds.

In the medium-investment environment, with the appearance of the first trifolium developed, corresponding to the V2 stage [12], with Bradyrhizobium japonicum inoculant seeding line was sprayed at a dose of $5 \times 109 \mathrm{CFU} \mathrm{ml}^{-1}$ of bacterial concentration. At the same stage of development, for the high-investment environment, the Bradyrhizobium japonicum inoculant dose was $12.5 \times 109 \mathrm{CFU}$ $\mathrm{ml}^{-1}$ of bacterial concentration, in addition to cobalt and molybdenum foliar spraying in the amounts of 0.145 and $2.54 \mathrm{~g} \cdot \mathrm{ha}^{-1}$ of a.i., respectively, with a syrup volume of $200 \mathrm{~L} \cdot \mathrm{ha}^{-1}$.

With the plants presenting three fully developed three-phase or four nodes, corresponding to the V4 stage, weed control was applied in a post-emergence area with application of glyphosate herbicide (1800 g.ha ${ }^{-1}$ of a.i) $250 \mathrm{~L} \cdot \mathrm{ha}^{-1}$. In addition, $13.10 \mathrm{~g} \cdot \mathrm{ha}^{-1}$ of $\mathrm{Mg}, 20.96 \mathrm{~g} \cdot \mathrm{ha}^{-1}$ of S, $6.55 \mathrm{~g} \cdot \mathrm{ha}^{-1}$ of B, $6.55 \mathrm{~g} \cdot \mathrm{ha}^{-1}$ of $\mathrm{Cu}$, $78.6 \mathrm{~g} \cdot \mathrm{ha}^{-1}$ of Mn, $3.93 \mathrm{~g} \cdot \mathrm{ha}^{-1}$ of Mo and $39.30 \mathrm{~g} \cdot \mathrm{ha}^{-1}$ of $\mathrm{Zn}$. At the end of the vegetative period and at the beginning of the reproductive stage, glyphosate was applied in the total area at the same doses and volume of application. In the high-investment environment, in addition to glyphosate an additional application of micronutrients was carried out, in the same amounts described previously.

With the identification of the reproductive stage $\mathrm{R} 2$ in all the cultivars in the high investment environment, a preventive fungicide application was carried out with the application of $66.5 \mathrm{~g} \cdot \mathrm{ha}^{-1}$ of a.i. pyraclostrobin and $25 \mathrm{~g} \cdot \mathrm{ha}^{-1}$ of a.i. of epoxiconazole. After this application, leaf sprays with crystallized monoammonium phosphate were applied at a dose of $0.30 \mathrm{~kg} \cdot \mathrm{ha}^{-1}$ of $\mathrm{N}$ and $1.52 \mathrm{~kg} \cdot \mathrm{ha}^{-1}$ of $\mathrm{P}_{2} \mathrm{O}_{5}+1.50 \mathrm{~kg} \cdot \mathrm{ha}^{-1}$ of Calcium Nitrate. In the medium investment environment, only $66.5 \mathrm{~g} \cdot \mathrm{ha}^{-1}$ of the a.i. pyraclostrobin and $25 \mathrm{~g} \cdot \mathrm{ha}^{-1}$ of a.i. of epoxiconazole.

At the reproductive stages comprised between R3 phases $(0.5 \mathrm{~cm}$ to $2.0 \mathrm{~cm}$ pod in one of the four upper nodes on the main stem) to R4 (fully developed pod $(>2.0 \mathrm{~cm})$ at one of the four upper nodes in the main stem) was carried out only 
in the high investment environment the application of fungicide in a preventive way with the application of $70 \mathrm{~g} \cdot \mathrm{ha}^{-1}$ of a.i. trifloxystrobin. After this application, leaf sprays with crystallized monoammonium phosphate were applied at a dose of $0.30 \mathrm{~kg} \cdot \mathrm{ha}^{-1}$ of $\mathrm{N}$ and $1.52 \mathrm{~kg} \cdot \mathrm{ha}^{-1}$ of $\mathrm{P}_{2} \mathrm{O}_{5}+1.50 \mathrm{~kg} \cdot \mathrm{ha}^{-1}$ of calcium nitrate.

The phenological stage evaluations were performed weekly by means of the visual evaluation of the experimental units and adopting the phenological scale of [12]. The date of the emergency was considered when $50 \%$ of the plants were with the cotyledons above the ground and the durations, in days, of the emergency to the V4 stage were determined; the last vegetative stage; the period of overlap (period of transition between the vegetative and reproductive stages) according to Zanon et al. [5], start from R1 to R5.

On 10/3/2016, together with the evaluation of the phenological stage, the chlorophyll content and the Normalized Difference Vegetation Index (NDVI) were evaluated using SPAD and GreenSeker portable equipment. For each plot, 10 readings with SPAD were performed, in the central leaflet of the third open trefoil from the apex to the base of the plant, in ten plants per plot. For NDVI, the GreenSeker ${ }^{\circledR}$ was positioned on the center line of each plot at a height of 40 $\mathrm{cm}$ from the plant canopy.

On the basis of the RMG cultivars were two harvest times, from the identification of full physiological maturity (over 95\% of mature pods staining). Thus, cultivar M 6210, M 6410, RK 5813, TMG 2158 and Flecha were harvested at 94 days after emergence and BRS 7780 cultivars BRS 8180, NS7300, PP7500 and ST 797 were harvested at 101 days after emergence.

Before the harvest, in the useful area of each experimental unit, the plants were counted to estimate the final stand. After the counting, 10 plants were separated from the useful area to evaluate the agronomic characteristics: height of plants (realized by reading in ruler graduated in centimeters the distance between the insertion of the last pods at the apex and the cut-off point of the plants at the level from soil); number of pods per plant, number of grains per pod and number of grains per pod (separation and counting of pods and grains); (mechanical threshing of the pods, grain weighing and separation of 8 samples 300 grain, the values extrapolated to $130 \mathrm{~g} \cdot \mathrm{kg}^{-1}$ of water).

The variables were submitted to analysis of joint variance, in order to verify the existence of interaction between cultivars and investment in fertilization environments. The Scott-Knott averages test $(p>0.05)$ was used for the comparison of treatments, using the SISVAR statistical program [13].

\section{Results and Discussion}

In Table 3 are the results of the interval in days of the four phenological stages of soybean evaluation, in addition to the maximum and minimum average temperatures and rainfall for each evaluation period. It was found that the maximum temperature was higher than the average of the last 10 years. This variation did not occur for the minimum temperature. In addition, accumulated rainfall 
Table 3. Interval in days of soybean development stages, mean maximum and minimum temperatures, cumulative rainfall during evaluation periods, and climatic mean of the last 10 years from December to April. Sete Lagoas-MG, agriculturalyear 2015/2016.

\begin{tabular}{|c|c|c|c|c|}
\hline \multirow{2}{*}{ Phenologicalstages } & \multirow{2}{*}{$\begin{array}{c}\text { Interval } \\
\text { Days }\end{array}$} & \multicolumn{2}{|c|}{ Temperature $\left({ }^{\circ} \mathrm{C}\right)$} & \multirow{2}{*}{$\begin{array}{c}\text { Precipitation } \\
\mathrm{mm}\end{array}$} \\
\hline & & Maximum & Minimum & \\
\hline Emergency-V4 & 24 & 31.7 & 18.1 & 84.5 \\
\hline Last vegetative stage & 37 & 30.5 & 18.7 & 383.4 \\
\hline Overlay & 7 & & 19.0 & 53.3 \\
\hline R1- R5 & 36 & 33.8 & 18.5 & 42.9 \\
\hline Temperature averages $\left({ }^{\circ} \mathrm{C}\right)$ & --o-- & 32.2 & 18.6 & 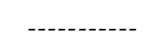 \\
\hline Total precipitation (mm) & ----o--- & --------- & -------- & 564.1 \\
\hline Average 10 years $(2005-2015)$ & 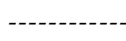 & 29.9 & 16.4 & 847.9 \\
\hline
\end{tabular}

during the development period was $33 \%$ lower than the average of the last decade, indicating that during the growing season there were high temperatures, especially in the reproductive phase. About $67 \%$ of all accumulated precipitation was concentrated in the vegetative phase. Moreover, the cumulative precipitation during the soybean driving period is in the interval considered ideal for the crop that, according to Farias et al. [14], can range from 450 to $800 \mathrm{~mm}$ per cycle. According to the authors, the need for water increases with the development of the plant, reaching the maximum during the flowering phases until the filling of grains, reaching $7-8 \mathrm{~mm}$ per day.

When analyzing the number of days elapsed between phases R1 to R5 (Table 4) and multiplying by water demand at this stage, it was observed that the ideal water requirement for soybean would be $252 \mathrm{~mm}$, however, the amount of accumulated precipitation was of $42.9 \mathrm{~mm}$, much less than the required quantity. From this information, it was found that during the conduction of the experiment the water demand for the soybean was sufficient during the vegetative phase, but inferior in the reproductive phase, indicating a water restriction in the stage of grain filling. The highest concentration of water in the vegetative phase influenced the agronomic characteristics, especially plant height and lodging (Table 6). The lower precipitation allied to high temperature in the reproductive phase also contributed to the productivity and mass differences of 300 grains among the cultivars (Table 9), mainly in cultivars with a 101 day cycle.

Table 4 shows the values corresponding to the number of days between emergence and V4 stage (three fully developed trifles or four nodes) and emergence up to the vegetative stage of the soybean cultivars as a function of the investment in fertilization environments. It can be observed that in the average of the two evaluated periods, the investment environments did not influence the duration of the phenological phases. The differences between the phases occurred as a function of the cultivars, within each environment. The cultivar BRS 7780 presented the shortest duration between the emergence and the V4 phase, 
Table 4. Number of days between emergency and V4 stage and number of days between emergence and the last vegetative stage of soybean cultivars as a function of fertilization investment environments. Sete Lagoas-MG, agricultural year 2015/2016.

\begin{tabular}{ccccccc}
\hline & \multicolumn{2}{c}{ Emergency- $\mathrm{V}_{4}$ (days) } & \multicolumn{2}{c}{ Lastvegetativestage (days) } \\
\cline { 2 - 7 } Cultivars (cycle) & \multicolumn{2}{c}{ Investment } & & \multicolumn{2}{c}{ Investiment } & Average \\
& Medium & High & & Medium & High & \\
\hline M 6210 (94d) & $25 \mathrm{a}$ & $28 \mathrm{a}$ & $26 \mathrm{a}$ & $35 \mathrm{c}$ & $37 \mathrm{~b}$ & $36 \mathrm{~d}$ \\
M 6410 (94 d) & $24 \mathrm{a}$ & $25 \mathrm{~b}$ & $25 \mathrm{~b}$ & $37 \mathrm{~b}$ & $37 \mathrm{~b}$ & $37 \mathrm{c}$ \\
RK 5813(94 d) & $24 \mathrm{a}$ & $25 \mathrm{~b}$ & $24 \mathrm{~b}$ & $30 \mathrm{~d}$ & $30 \mathrm{c}$ & $30 \mathrm{e}$ \\
TMG 2158 (94 d) & $24 \mathrm{a}$ & $25 \mathrm{~b}$ & $24 \mathrm{~b}$ & $30 \mathrm{~d}$ & $30 \mathrm{c}$ & $30 \mathrm{e}$ \\
Flecha (94 d) & $24 \mathrm{a}$ & $27 \mathrm{a}$ & $25 \mathrm{~b}$ & $37 \mathrm{~b}$ & $37 \mathrm{~b}$ & $37 \mathrm{c}$ \\
BRS 7780 (101 d) & $20 \mathrm{~b}$ & $19 \mathrm{~d}$ & $19 \mathrm{~d}$ & $44 \mathrm{a}$ & $44 \mathrm{a}$ & $44 \mathrm{a}$ \\
BRS 8180 (101 d) & $25 \mathrm{a}$ & $25 \mathrm{~b}$ & $25 \mathrm{~b}$ & $37 \mathrm{~b}$ & $44 \mathrm{a}$ & $40 \mathrm{a}$ \\
NS 7300 (101 d) & $24 \mathrm{a}$ & $22 \mathrm{c}$ & $23 \mathrm{~b}$ & $37 \mathrm{~b}$ & $37 \mathrm{~b}$ & $37 \mathrm{c}$ \\
PP 7500 (101 d) & $21 \mathrm{~b}$ & $22 \mathrm{c}$ & $22 \mathrm{c}$ & $37 \mathrm{~b}$ & $37 \mathrm{~b}$ & $37 \mathrm{c}$ \\
ST 797 (101 d) & $24 \mathrm{a}$ & $21 \mathrm{c}$ & $22 \mathrm{c}$ & $44 \mathrm{a}$ & $37 \mathrm{~b}$ & $40 \mathrm{a}$ \\
Average & $23 \mathrm{~A}$ & $24 \mathrm{~A}$ & & $37 \mathrm{~A}$ & $37 \mathrm{~A}$ & \\
CV (\%) & & 6.41 & & & 2.12 & \\
Overall Average & & 24 & & & 37 & \\
\hline
\end{tabular}

$\mathfrak{E}-$ Days after emergence. For each variable, averages followed by the same capital letter in the row and lowercase in the column do not differ from each other by the Scott-Knott test at $5 \%$ probability.

in the two evaluated environments. The highest significant variation among the cultivars occurred in the high investment environment; with cultivars of early cycle (94 days between emergences to physiological maturity) having a longer duration in this phase compared to longer cycle cultivars (101 days between emergences until the physiological maturity). On average, for cultivar M 6210 (94 cycle days) it took 26 days to reach V4 development stage, which was statistically superior to the others.

Although for BRS 7780 the number of days between emergence and V4 stage is statistically lower than the others, when analyzing the duration of the last vegetative stage, this cultivar had the highest values (Table 4). The behavior of this cultivar was statistically superior in the two investment environments, indicating that the duration of the vegetative stages for this cultivar does not depend on the technological level employed. When analyzing the duration of the vegetative phase for each cultivar, it is verified that the investment environments provided significant differences in a more pronounced way. The earlier cycle materials, which showed longer duration from emergence to the V4 stage, completed the vegetative cycle faster than the longer cycle cultivars. In both investment environments, cultivars RK 5813 and TMG 2158 completed the vegetative cycle in shorter duration compared to the others. This fact can be explained by the degree of maturity of these cultivars (5.8), being the earliest materials among the 
cultivars. Compared to M 6210 and M 6410 (with maturity level 6.2 and 6.4, respectively), the difference was 6 days in relation to the earliest cultivars, and for the cultivars with maturity degree 7.0 and 8.0 the difference varied between 7 days (for cultivars NS 7300, PP 7500 and BRS 8180) for up to 14 days (for cultivars BRS 7780 and ST 797). The results indicate that earlier cultivars present slower initial growth, but they complete the vegetative stage faster than cultivars with maturity levels above 7.0, mainly because they undergo a flowering with a lower number of vegetative stages, even at sowing times not recommended for early cultivars. This variation is independent of the investment environment in fertilization. The difference, in days, in the vegetative stage between the cultivars of degrees of maturity 5.0 for cultivars of degree of maturity 7.0 can vary between 7 to 14 days, depending on the cultivar.

Although for BRS 7780 the number of days between emergence and V4 stage is statistically lower than the others, when analyzing the duration of the last vegetative stage, this cultivar had the highest values (Table 4). The behavior of this cultivar was statistically superior in the two investment environments, indicating that the duration of the vegetative stages for this cultivar does not depend on the technological level employed. When analyzing the duration of the vegetative phase for each cultivar, it is verified that the investment environments provided significant differences in a more pronounced way. The earlier cycle materials, which showed longer duration from emergence to the V4 stage, completed the vegetative cycle faster than the longer cycle cultivars. In both investment environments, cultivars RK 5813 and TMG 2158 completed the vegetative cycle in shorter duration compared to the others. This fact can be explained by the degree of maturity of these cultivars (5.8), being the earliest materials among the cultivars. Compared to M 6210 and M 6410 (with maturity level 6.2 and 6.4, respectively), the difference was 6 days in relation to the earliest cultivars, and for the cultivars with maturity degree 7.0 and 8.0 the difference varied between 7 days (for cultivars NS 7300, PP 7500 and BRS 8180) for up to 14 days (for cultivars BRS 7780 and ST 797). The results indicate that earlier cultivars present slower initial growth, but they complete the vegetative stage faster than cultivars with maturity levels above 7.0, mainly because they undergo a flowering with a lower number of vegetative stages, even at sowing times not recommended for early cultivars. This variation is independent of the investment environment in fertilization. The difference, in days, in the vegetative stage between the cultivars of degrees of maturity 5.0 for cultivars of degree of maturity 7.0 can vary between 7 to 14 days, depending on the cultivar.

The period of overlap between the vegetative and reproductive phases varied significantly among cultivars, but was not influenced by the investment in fertilization environments (Table 5). Although in the cultivars average no significant differences were observed among the cultivars, it is observed in the environment of medium investment that the cultivar BRS 8180 presented period of superposition significantly superior to the others. In addition, in this investment 
Table 5. Overlap (days between the last vegetative stage and full bloom - R2) and number of days between the beginning of flowering (R1) to the stage of grain filling (R5) of soybean cultivars as a function of investment in fertilization environments. Sete Lagoas-MG, agricultural year 2015/2016.

\begin{tabular}{ccccccc}
\hline & \multicolumn{3}{c}{ Overlay (days) } & \multicolumn{3}{c}{$\mathrm{R}_{1}-\mathrm{R}_{5}$ (days) } \\
\cline { 2 - 5 } Cultivars (cycle) & \multicolumn{2}{c}{ Investment } & & \multicolumn{2}{c}{ Investment } & Average \\
\cline { 2 - 5 } & Medium & High & & Medium & High & \\
\hline M 6210 (94d) & $9 \mathrm{~b}$ & $7 \mathrm{~b}$ & $8 \mathrm{a}$ & $36 \mathrm{~d}$ & $36 \mathrm{~b}$ & $36 \mathrm{c}$ \\
M 6410 (94 d) & $7 \mathrm{c}$ & $7 \mathrm{~b}$ & $7 \mathrm{a}$ & $36 \mathrm{~d}$ & $36 \mathrm{~b}$ & $36 \mathrm{c}$ \\
RK 5813(94 d) & $7 \mathrm{c}$ & $7 \mathrm{~b}$ & $7 \mathrm{a}$ & $41 \mathrm{~b}$ & $43 \mathrm{a}$ & $42 \mathrm{a}$ \\
TMG 2158 (94 d) & $7 \mathrm{c}$ & $7 \mathrm{~b}$ & $7 \mathrm{a}$ & $43 \mathrm{a}$ & $36 \mathrm{~b}$ & $39 \mathrm{~b}$ \\
Flecha (94 d) & $7 \mathrm{c}$ & $7 \mathrm{~b}$ & $7 \mathrm{a}$ & $29 \mathrm{f}$ & $36 \mathrm{~b}$ & $32 \mathrm{~d}$ \\
BRS 7780 (101 d) & $4 \mathrm{~d}$ & $4 \mathrm{c}$ & $4 \mathrm{a}$ & $32 \mathrm{e}$ & $32 \mathrm{c}$ & $32 \mathrm{~d}$ \\
BRS 8180 (101 d) & $11 \mathrm{a}$ & $4 \mathrm{c}$ & $7,5 \mathrm{a}$ & $39 \mathrm{c}$ & $32 \mathrm{c}$ & $35 \mathrm{c}$ \\
NS 7300 (101 d) & $7 \mathrm{c}$ & $7 \mathrm{~b}$ & $7 \mathrm{a}$ & $36 \mathrm{~d}$ & $36 \mathrm{~b}$ & $36 \mathrm{c}$ \\
PP 7500 (101 d) & $7 \mathrm{c}$ & $7 \mathrm{~b}$ & $7 \mathrm{a}$ & $36 \mathrm{~d}$ & $36 \mathrm{~b}$ & $36 \mathrm{c}$ \\
ST 797 (101 d) & $4 \mathrm{~d}$ & $11 \mathrm{a}$ & $7 \mathrm{a}$ & $37 \mathrm{~d}$ & $32 \mathrm{c}$ & $35 \mathrm{c}$ \\
Average & $7 \mathrm{~A}$ & $7 \mathrm{~A}$ & & $36 \mathrm{~B}$ & $35 \mathrm{~A}$ & \\
CV (\%) & & 11.36 & & & 3.13 & \\
Overall Average & & 7 & & & 36 & \\
\hline
\end{tabular}

$\mathfrak{E}-$ Days after emergence. For each variable, averages followed by the same capital letter in the row and lowercase in the column do not differ from each other by the Scott-Knott test at $5 \%$ probability.

environment, the variations between the cultivars were larger compared to the high investment environment. In two cultivars there were inverse variations in the overlapping period, due to the investment environment. In the cultivar BRS 8180, the highest investment in fertilization provided a shorter overlap period, being the inverse for cultivar ST 797. According to Heatherly et al. [15] and Zanon et al. [5] in late or late sowing, the duration of the vegetative and reproductive phase overlapping period may change according to the meteorological conditions during the development cycle, causing variations in the growth habit of a cultivar. Thus, it is possible to infer that the results found in this work can be due to the late sowing season (December), which affected in the development cycle of the cultivars, indicating that, in these cultivars, there were more vegetative stages in relation to the other cultivars. This inference stems from the fact that, when observing the last vegetative stage (Table 4), the two cultivars presented values statistically superior to the other cultivars, indicating a greater number of vegetative stages until the beginning of the flowering.

In relation to the number of days between the R1 stage (beginning of flowering) to the R5 stage (beginning of the grain filling - $<10 \%$ of granulation) in one of the four upper nodes in the main stem, there was a significant influence of the cultivar factors and investment environment (Table 5). The investment in ferti- 
lization provided a shorter duration between phases R1 to R5 ranging from 2 days for cultivar RK 5813 to 5 days for cultivar ST 797 and 7 days for cultivars TMG 2158 and BRS 8180. For cultivar Flecha, investment in fertilization implied in longer duration of the reproductive phases where the difference in relation to the medium investment environment of 7 days.

Analyzing the behavior of the cultivars in each environment, it was observed that the cultivars with cycle of 94 days presented the greatest variations, being cultivar TMG 2158 the longest period and Flecha the shortest period. These variations did not follow the same trend in the high investment environment. The cultivar RK 5813 presented the longest duration of these phases and cultivars BRS 7780, BRS 8180 and ST 797 obtained periods of duration statistically inferior to the others.

Thus, from the average results, it is possible to infer that cultivars with higher degrees of maturity and with a development cycle of 101 days presented a longer development period in the vegetative phase (40 days on average) (Table 4). Thus, discounting the number of days to complete the cycle and the vegetative period, the period of the reproductive phase was 61 days. Performing the same calculation for cultivars with a cycle of 94 days, the reproductive period was 60 days, on average. Thus, it is possible to infer that the earliest materials have the shortest vegetative cycle and, even with overlapping and reproductive periods similar to the later cultivars, the sowing period is decisive so that these materials can express the maximum productive potential. In later sowing, especially in regions with water restrictions or with irregular rainfall distributions in the summer, cultivars with a later cycle may present better adaptability due to the longer vegetative period. This feature may be interesting because, if water restrictions occur in flowering, the influence on productivity will be greater.

The final plant stand was significantly influenced by the cultivars (Table 6). The cultivars M 6410, Flecha, NS 7300 and PP 7500 obtained the highest values of final stand in the two investment environments and cultivars RK 5813, TMG 2158 and BRS 7780 the lowest values. On average, the largest populations were found in cultivars M 6210, M 6410, Flecha, NS 7300, PP 7500 and ST 797.

The levels of investment in fertilization influenced plant height (Table 6). The higher level of investment provided higher plant height. The significant differences observed in the medium investment environment followed the same trend in the high investment environment. At the mean investment level, the highest heights were found in cultivars with 101 days cycle (ST 797, BRS 8180 and BRS 7780 ) with heights of $106.3,108.8$ and $100.7 \mathrm{~cm}$, respectively. These same cultivars also presented the highest heights in the high investment environment. The same happened with cultivars RK 5813, TMG 2158 that presented the lowest heights in both environments. On average, BRS8180 and ST797 presented higher plant heights and RK5813, TMG2158 and NS7300 the lowest.

The height of plants is a characteristic linked to genetics and, in the case of this experiment, the investment in fertilization favored the expression of this 
Table 6. Final stand, plant height and lodging of soybean cultivars according to the fertilization investment environments. Sete Lagoas-MG, agricultural year 2015/2016.

\begin{tabular}{|c|c|c|c|c|c|c|c|c|}
\hline \multirow{3}{*}{ Cultivars $(\text { cycle })^{t}$} & \multicolumn{3}{|c|}{ Final stand (plants.ha ${ }^{-1}$ ) } & \multicolumn{3}{|c|}{ Plant Height (m) } & \multirow{2}{*}{\multicolumn{2}{|c|}{$\begin{array}{c}\text { Lodging }^{\mathrm{T}} \\
\text { Investment }\end{array}$}} \\
\hline & \multicolumn{2}{|c|}{ Investment } & \multirow{2}{*}{ Average } & \multicolumn{2}{|c|}{ Investment } & \multirow{2}{*}{ Average } & & \\
\hline & Medium & High & & Medium & High & & Medium & High \\
\hline M $6210(94 d)$ & $284687 \mathrm{~b}$ & 299687 a & 292187 a & $80.5 \mathrm{~d}$ & $91.1 \mathrm{c}$ & $85.8 \mathrm{~d}$ & 1 & 2 \\
\hline M 6410 (94 d) & 315625 a & $311875 \mathrm{a}$ & 313750 a & $84.8 \mathrm{~d}$ & $88.1 \mathrm{c}$ & $86.5 \mathrm{~d}$ & 1 & 1 \\
\hline RK 5813(94 d) & $275312 b$ & $264062 \mathrm{~b}$ & $269687 \mathrm{~b}$ & $69.4 \mathrm{e}$ & $76.9 \mathrm{~d}$ & $73.1 \mathrm{e}$ & 1 & 1 \\
\hline TMG 2158 (94 d) & $276562 \mathrm{~b}$ & $276250 \mathrm{~b}$ & 276406 b & $71.4 \mathrm{e}$ & $81.3 \mathrm{~d}$ & $76.4 \mathrm{e}$ & 1 & 1 \\
\hline Flecha (94 d) & 299375 a & $290000 \mathrm{a}$ & 294687 a & $83.3 \mathrm{~d}$ & $94.4 \mathrm{c}$ & $88.8 \mathrm{~d}$ & 1 & 2 \\
\hline BRS 7780 (101 d) & $283437 \mathrm{~b}$ & $279687 \mathrm{~b}$ & 281562 b & $100.7 \mathrm{~b}$ & $109.6 \mathrm{a}$ & $105.1 \mathrm{~b}$ & 3 & 4 \\
\hline BRS 8180 (101 d) & 292812 a & $275312 \mathrm{~b}$ & $284062 \mathrm{~b}$ & $108.8 \mathrm{a}$ & $117.5 \mathrm{a}$ & $113.2 \mathrm{a}$ & 2 & 3 \\
\hline NS 7300 (101 d) & $295000 \mathrm{a}$ & 301562 a & $298281 \mathrm{a}$ & $78.2 \mathrm{~d}$ & $84.9 \mathrm{~d}$ & $81.6 \mathrm{e}$ & 1 & 1 \\
\hline PP $7500(101 \mathrm{~d})$ & 304687 a & $303750 \mathrm{a}$ & 304219 a & $93.6 \mathrm{c}$ & $100.0 \mathrm{~b}$ & $96.8 \mathrm{c}$ & 1 & 1 \\
\hline ST $797(101 \mathrm{~d})$ & $283125 \mathrm{~b}$ & $297500 \mathrm{a}$ & 290312 a & $106.3 \mathrm{a}$ & $112.7 \mathrm{a}$ & $109.5 \mathrm{a}$ & 2 & 4 \\
\hline Average & 291062 A & 289969 A & & 87.7 B & $95.7 \mathrm{~A}$ & & & \\
\hline CV (\%) & & 6.11 & & & 4.89 & & & \\
\hline Overall Average & & 290516 & & & 91.7 & & & \\
\hline
\end{tabular}

$\mathcal{E}-$ Days after emergency. $\mathrm{F}-$ Note $1=$ no bedridden plant; Note $2=25 \%$ of bedded plants; Note $3=50 \%$ of bedded plants; Note $4=75 \%$ of bedded plants; Note $5=100 \%$ of bedded plants.

phenomenon. In addition, when analyzing plant height data (Table 6) with the number of days between emergence and the last vegetative stage (Table 4), it was found that the cultivars that presented the highest heights were statically superior also in the duration of the vegetative stage. The same analogy can also be made for the cultivars that obtained the lowest heights. Thus, in addition to genetic expression and investment in fertilization, the duration of the vegetative stage determines the agronomic characteristics, such as number of nodes, inflorescence, number of branches and pods per plant [5].

The lodging also presented a direct relation with the height of plants and, consequently, with the duration of the vegetative stage. The highest plant heights identified in medium and high investment environments also provided the highest lodging rates (Table 6). Among the cultivars analyzed, BRS 7780 was the one that obtained the highest indices, in both environments of investment in fertilization, being superior to $50 \%$ of bedded plants. The cultivar ST 797 was influenced by fertilization, as the greater investment increased the number of plants in bed being higher than $75 \%$ in this environment. The same occurred with cultivars BRS 8180, M 6210 and Flecha, but to a lesser extent. From the results obtained in this experiment, it can be inferred that the duration of the vegetative stage in the cultivars with a development cycle of 101 days influenced the height, causing more bedding. This may be due to climatic conditions during the experiment. 
The investment levels did not significantly influence the number of pods per plant, however, the higher investment in fertilization provided increases in the number of grains (Table 7). In the cultivars average, materials RK 5813, BRS 7780, BRS 8180, PP7500 and ST 797 obtained the highest values for number of pods per plant. With the exception of cultivars BRS 8180 and PP7500, these materials also culminated with higher average number of grains per plant and number of grains per pod in the two fertilization environments. In the medium-investment environment, cultivars RK 5813, BRS 7780 and ST 797 presented the highest number of grains per plant, which was repeated in the environment of higher investment. The cultivars M 6410, Flecha and BRS 8180 presented the lowest values of number of grains per plant in the two fertilization environments. When analyzing the number of grains per pod, it was verified that only the cultivar BRS 8180 followed the same trend, being statistically lower in the number of grains per pod independent of the investment in fertilization (Table 7). In addition, with the exception of the cultivar Flecha, the cultivars that presented the lowest numbers of grains per plant also presented statistically lower values for the number of grains per pod in the same investment environment.

Table 8 shows the values referring to the mass of 300 grains and grain yield of the soybean cultivars as a function of the investment in fertilization environments. In both variables, the greater investment gave a greater mass of 300

Table 7. Number of pods per plant, number of grains per plant and number of grains per pod of soybean cultivars as a function of fertilization investment environments. Sete Lagoas-MG, agricultural year 2015/2016.

\begin{tabular}{|c|c|c|c|c|c|c|c|c|c|}
\hline \multirow{3}{*}{ Cultivars $(\text { cycle })^{E}$} & \multicolumn{3}{|c|}{ Pods per plant $\left(\mathrm{n}^{\circ}\right)$} & \multicolumn{3}{|c|}{ Grains per plant $\left(\mathrm{n}^{\circ}\right)$} & \multicolumn{3}{|c|}{ Grains per pod $\left(n^{\circ}\right)$} \\
\hline & \multicolumn{2}{|c|}{ Investment } & \multirow{2}{*}{ Average } & \multicolumn{2}{|c|}{ Investment } & \multirow{2}{*}{ Average } & \multicolumn{2}{|c|}{ Investment } & \multirow{2}{*}{ Average } \\
\hline & Medium & High & & Medium & High & & Medium & High & \\
\hline M $6210(94 d)$ & $61.7 \mathrm{a}$ & $86.1 \mathrm{a}$ & $73.9 \mathrm{~b}$ & $122 \mathrm{~b}$ & $179 \mathrm{a}$ & $150 \mathrm{~b}$ & $2.0 \mathrm{a}$ & $2.1 \mathrm{a}$ & $2.0 \mathrm{~b}$ \\
\hline M $6410(94 \mathrm{~d})$ & $70.2 \mathrm{a}$ & $71.3 \mathrm{a}$ & $70.8 \mathrm{~b}$ & $132 \mathrm{~b}$ & $150 \mathrm{~b}$ & $141 \mathrm{~b}$ & $1.9 \mathrm{a}$ & $2.1 \mathrm{a}$ & $2.0 \mathrm{~b}$ \\
\hline RK 5813(94 d) & $82.2 \mathrm{a}$ & $82.1 \mathrm{a}$ & $82.2 \mathrm{a}$ & $194 \mathrm{a}$ & $187 \mathrm{a}$ & $191 \mathrm{a}$ & $2.3 \mathrm{a}$ & $2.3 \mathrm{a}$ & $2.3 \mathrm{a}$ \\
\hline TMG 2158 (94 d) & $73.0 \mathrm{a}$ & $73.3 \mathrm{a}$ & $73.2 \mathrm{~b}$ & $139 \mathrm{~b}$ & $170 \mathrm{a}$ & $155 \mathrm{~b}$ & $1.9 \mathrm{a}$ & $2.3 \mathrm{a}$ & $2.1 \mathrm{~b}$ \\
\hline Flecha (94 d) & $63.7 \mathrm{a}$ & $60.6 \mathrm{a}$ & $62.2 \mathrm{~b}$ & $135 \mathrm{~b}$ & $150 \mathrm{~b}$ & $142 \mathrm{~b}$ & $2.1 \mathrm{a}$ & $2.5 \mathrm{a}$ & $2.3 \mathrm{a}$ \\
\hline BRS $7780(101 \mathrm{~d})$ & $79.2 \mathrm{a}$ & $89.4 \mathrm{a}$ & $84.3 \mathrm{a}$ & $172 \mathrm{a}$ & $207 \mathrm{a}$ & $190 \mathrm{a}$ & $2.2 \mathrm{a}$ & $2.5 \mathrm{a}$ & $2.3 \mathrm{a}$ \\
\hline BRS $8180(101 \mathrm{~d})$ & $78.8 \mathrm{a}$ & $80.4 \mathrm{a}$ & $79.6 \mathrm{a}$ & $111 \mathrm{~b}$ & $125 \mathrm{~b}$ & $118 \mathrm{~b}$ & $1.4 \mathrm{~b}$ & $1.5 \mathrm{~b}$ & $1.5 \mathrm{c}$ \\
\hline NS 7300 (101 d) & $70.6 \mathrm{a}$ & $78.6 \mathrm{a}$ & $74.6 \mathrm{~b}$ & $121 \mathrm{~b}$ & $173 \mathrm{a}$ & $147 \mathrm{~b}$ & $1.7 \mathrm{~b}$ & $2.2 \mathrm{a}$ & $2.0 \mathrm{~b}$ \\
\hline PP 7500 (101 d) & $84.4 \mathrm{a}$ & $80.5 \mathrm{a}$ & $82.5 \mathrm{a}$ & $141 \mathrm{~b}$ & $166 \mathrm{a}$ & $154 \mathrm{~b}$ & $1.7 \mathrm{~b}$ & $2.1 \mathrm{a}$ & $1.9 \mathrm{~b}$ \\
\hline ST 797 (101 d) & $85.9 \mathrm{a}$ & $103.4 \mathrm{a}$ & $94.7 \mathrm{a}$ & $170 \mathrm{a}$ & $208 \mathrm{a}$ & $189 a$ & $2.0 \mathrm{a}$ & $2.0 \mathrm{a}$ & $2.0 \mathrm{~b}$ \\
\hline Average & $75.0 \mathrm{~A}$ & $80.6 \mathrm{~A}$ & & $144 \mathrm{~B}$ & $171 \mathrm{~A}$ & & $1.9 \mathrm{~B}$ & $2.2 \mathrm{~A}$ & \\
\hline CV (\%) & & 18.03 & & & 16.75 & & & 14.00 & \\
\hline Overall Average & & 77.8 & & & 157.7 & & & 2.0 & \\
\hline
\end{tabular}

E_Days after emergency. For each variable, Averages followed by the same capital letter in the row and lowercase in the column do not differ from each other by the Scott-Knott test at $5 \%$ probability. 
Table 8. 300 grains mass and grain yield of soybean cultivars as a function of investment in fertilization environments. Sete Lagoas-MG, agricultural year 2015/2016.

\begin{tabular}{|c|c|c|c|c|c|c|}
\hline \multirow{3}{*}{ Cultivars $(\text { cycle })^{\epsilon}$} & \multicolumn{3}{|c|}{300 grains mass (g) } & \multicolumn{3}{|c|}{ Grain Productivity $\left(\mathrm{kg} \cdot \mathrm{ha}^{-1}\right)$} \\
\hline & \multicolumn{2}{|c|}{ Investment } & \multirow{2}{*}{ Average } & \multicolumn{2}{|c|}{ Investment } & \multirow{2}{*}{ Average } \\
\hline & Medium & High & & Medium & High & \\
\hline M 6210 (94d) & $44.07 \mathrm{c}$ & $52.39 \mathrm{c}$ & $48.23 \mathrm{~d}$ & 3139 a & $3726 \mathrm{~b}$ & $3433 \mathrm{~b}$ \\
\hline M 6410 (94 d) & $48.31 \mathrm{c}$ & $59.50 \mathrm{~b}$ & $53.90 \mathrm{c}$ & $3406 \mathrm{a}$ & $3757 \mathrm{~b}$ & $3581 \mathrm{~b}$ \\
\hline RK 5813(94 d) & $47.23 \mathrm{c}$ & $57.46 \mathrm{c}$ & $52.34 \mathrm{c}$ & 3503 a & $4600 \mathrm{a}$ & $4051 \mathrm{a}$ \\
\hline TMG 2158 (94 d) & $54.06 \mathrm{~b}$ & $64.89 \mathrm{~b}$ & $59.50 \mathrm{~b}$ & $3162 \mathrm{a}$ & $3923 \mathrm{~b}$ & $3542 \mathrm{~b}$ \\
\hline Flecha (94 d) & $63.04 \mathrm{a}$ & $70.38 \mathrm{a}$ & $66.71 \mathrm{a}$ & $3520 \mathrm{a}$ & $3482 \mathrm{c}$ & $3500 \mathrm{~b}$ \\
\hline BRS 7780 (101 d) & $46.70 \mathrm{c}$ & $62.54 \mathrm{~b}$ & $54.62 \mathrm{c}$ & $2596 \mathrm{~b}$ & $3147 \mathrm{c}$ & $2872 \mathrm{c}$ \\
\hline BRS 8180 (101 d) & $49.15 \mathrm{c}$ & $60.85 \mathrm{~b}$ & $55.00 \mathrm{c}$ & $2165 \mathrm{~b}$ & $2781 \mathrm{~d}$ & $2473 \mathrm{~d}$ \\
\hline NS 7300 (101 d) & $61.87 \mathrm{a}$ & $69.12 \mathrm{a}$ & $65.50 \mathrm{a}$ & $3482 \mathrm{a}$ & $3936 \mathrm{~b}$ & $3709 \mathrm{~b}$ \\
\hline PP 7500 (101 d) & $47.13 \mathrm{c}$ & $63.45 \mathrm{~b}$ & $55.29 \mathrm{c}$ & $3228 \mathrm{a}$ & $4214 \mathrm{a}$ & $3721 \mathrm{~b}$ \\
\hline ST 797 (101 d) & $37.31 \mathrm{~d}$ & $48.54 \mathrm{c}$ & $42.92 \mathrm{~d}$ & $2932 \mathrm{a}$ & $3257 \mathrm{c}$ & $3094 \mathrm{c}$ \\
\hline Average & $49.89 \mathrm{~B}$ & $60.91 \mathrm{~A}$ & & $3113 \mathrm{~B}$ & $3682 \mathrm{~A}$ & \\
\hline CV (\%) & & 9.52 & & & 9.42 & \\
\hline Overall Average & & 55.4 & & & 3398 & \\
\hline
\end{tabular}

E-Days after emergence. For each variable, averages followed by the same capital letter in the row and lowercase in the column do not differ from each other by the Scott-Knott test at $5 \%$ probability.

grains and greater productivity. For the mass of 300 grains, the cultivars Flecha and NS 7300 presented the highest values and the cultivars M 6210 and ST 797 the lowest, in both environments. For the grain yield, in the medium investment environment, the cultivars BRS 7780 and BRS 8180 were statistically inferior to the others and in the high investment environment the cultivar BRS 8180 obtained inferior productivity. On average, the highest grain yield was obtained in cultivar RK 5813 (4051 kg.ha ${ }^{-1}$ ) and the lowest yield was the cultivar BRS 8180 $\left(2473 \mathrm{~kg} \cdot \mathrm{ha}^{-1}\right)$. The highest soybean yield among the evaluated treatments was obtained in cultivar RK 5813 in the high-investment environment, with 4600 $\mathrm{kg} \cdot \mathrm{ha}^{-1}$ and the lowest productivity in the cultivar BRS 8180 with medium investment $\left(2165 \mathrm{~kg} \cdot \mathrm{ha}^{-1}\right)$.

When analyzing the productivity values in the two investment environments, it was verified that the contingency in the investment in fertilization caused yields below the state average (3220 kg.ha- ${ }^{-1}$ ) for cultivars M6210, TMG 2158, BRS7780, BRS8180 and ST797 did not occur in high investment environment. In this environment, only cultivars BRS 8180 and BRS7780 presented grain yields below the state average verified in the 2015/16 harvest by National Supply Company [1]. Thus, even in the central region of Minas Gerais, characterized by restrictive climatic conditions to soybean cultivation due to water restriction during the summer period, the combination of cultivars with contrasting cycles combined with the investment in fertilization can provide productivity above the 
state average. From the results verified in this experiment, only the cultivars BRS 7780 , BRS 8180 and ST 797 would have greater cultivation restrictions in this region, because they present productivities lower than the state average. For the case of the selection of these materials, it is recommended more investment in fertilization.

The chlorophyll content (SPAD index) and the Normalized Difference Vegetation Index (NDVI) were influenced by the investment environments, although inversely proportional (Table 9). The average level of investment provided higher chlorophyll content, with the reverse for NDVI values. When analyzing the cultivars in each investment environment, it was verified that only in the high investment environment there were significant differences for the chlorophyll content. The cultivars with a development cycle of 101 days had chlorophyll levels higher than the cultivars with 94 days of cycle, with the materials BRS 8180 and ST 797 SPAD values statistically superior to the others. In the cultivars average, the ST 797 material had the SPAD value higher than the other cultivars.

As in the SPAD values, the mean investment in fertilization did not provide a significant difference between cultivars for NDVI (Table 10). In the high investment environment, the cultivars Flecha and TMG2158 showed the lowest values. In the cultivars average, the materials RK 5813, BRS7780, BRS8180 and

Table 9. Chlorophyll content (SPAD) and Normalized Difference Vegetation Index (NDVI) of soybean cultivars as a function of fertilization investment environments. Sete Lagoas-MG, agricultural year 2015/2016.

\begin{tabular}{|c|c|c|c|c|c|c|}
\hline \multirow{3}{*}{ Cultivars $(\text { cycle })^{\epsilon}$} & \multicolumn{3}{|c|}{ SPAD } & \multicolumn{3}{|c|}{ NDVI } \\
\hline & \multicolumn{2}{|c|}{ Investment } & \multirow{2}{*}{ Average } & \multicolumn{2}{|c|}{ Investment } & \multirow[t]{2}{*}{ Average } \\
\hline & Medium & High & & Medium & High & \\
\hline M 6210 (94d) & $41.60 \mathrm{a}$ & $36.90 \mathrm{c}$ & $39.25 \mathrm{~d}$ & $0.72 \mathrm{a}$ & $0.76 \mathrm{~b}$ & $0.74 \mathrm{~b}$ \\
\hline M $6410(94 \mathrm{~d})$ & $44.40 \mathrm{a}$ & $39.32 \mathrm{c}$ & $41.86 \mathrm{c}$ & $0.77 \mathrm{a}$ & $0.78 \mathrm{~b}$ & $0.77 \mathrm{~b}$ \\
\hline RK 5813(94 d) & $46.35 \mathrm{a}$ & $43.10 \mathrm{c}$ & $44.72 \mathrm{~b}$ & $0.78 \mathrm{a}$ & $0.79 \mathrm{a}$ & $0.79 \mathrm{a}$ \\
\hline TMG 2158 (94 d) & $43.07 \mathrm{a}$ & $37.65 \mathrm{c}$ & $40.36 \mathrm{~d}$ & $0.75 \mathrm{a}$ & $0.73 c$ & $0.74 \mathrm{~b}$ \\
\hline Flecha (94 d) & $44.60 \mathrm{a}$ & $40.35 c$ & $42.47 \mathrm{c}$ & $0.75 \mathrm{a}$ & $0.72 \mathrm{c}$ & $0.73 \mathrm{~b}$ \\
\hline BRS $7780(101 \mathrm{~d})$ & $45.60 \mathrm{a}$ & $45.95 \mathrm{~b}$ & $45.77 \mathrm{~b}$ & $0.76 \mathrm{a}$ & $0.80 \mathrm{a}$ & $0.78 \mathrm{a}$ \\
\hline BRS $8180(101 \mathrm{~d})$ & $46.00 \mathrm{a}$ & $48.80 \mathrm{a}$ & $47.40 \mathrm{~b}$ & $0.79 \mathrm{a}$ & $0.82 \mathrm{a}$ & $0.80 \mathrm{a}$ \\
\hline NS $7300(101 \mathrm{~d})$ & $43.00 \mathrm{a}$ & $41.40 \mathrm{c}$ & $42.20 \mathrm{c}$ & $0.77 \mathrm{a}$ & $0.77 \mathrm{~b}$ & $0.77 \mathrm{~b}$ \\
\hline PP $7500(101 \mathrm{~d})$ & $43.57 \mathrm{a}$ & $44.35 \mathrm{~b}$ & $43.96 \mathrm{c}$ & $0.76 \mathrm{a}$ & $0.83 \mathrm{a}$ & $0.79 \mathrm{a}$ \\
\hline ST $797(101 \mathrm{~d})$ & $49.02 \mathrm{a}$ & $52.40 \mathrm{a}$ & $50.71 \mathrm{a}$ & $0.78 \mathrm{a}$ & $0.83 \mathrm{a}$ & $0.81 \mathrm{a}$ \\
\hline Average & $44.72 \mathrm{~A}$ & $43.02 \mathrm{~B}$ & & $0.76 \mathrm{~B}$ & $0.78 \mathrm{~A}$ & \\
\hline CV (\%) & & 6.90 & & & 4.31 & \\
\hline Overall Average & & 43.87 & & & 0.77 & \\
\hline
\end{tabular}

$\mathfrak{E}$-Days after emergency. For each variable, Averages followed by the same capital letter in the row and lowercase in the column do not differ from each other by the Scott-Knott test at $5 \%$ probability. 
Table 10. Pearson correlation coefficients ( $\mathrm{r}$ ) among final stand variables (ST), plant height (PH), number of pods per plant (NPP), number of grains per plant (NGP), number of grains per pod (NGP), 300 grains mass (300 M), Grain Productivity (PROD), chlorophyll content (SPAD) and Normalized Difference Vegetation Index (NDVI), obtained from the set of Averages of treatments of soybean cultivars and levels of fertilization. Sete Lagoas-MG, agricultural year 2015/2016.

\begin{tabular}{cccccccccc}
\hline & PH & NPP & NGP & NGP & $300 M$ & PROD & SPAD & NDVI & ST \\
\hline PH & 1 & 0.51 & 0.10 & -0.26 & -0.09 & $-0.51^{*}$ & 0.55 & 0.54 & 0.09 \\
NPP & & 1 & $0.67^{* *}$ & -0.02 & -0.31 & -0.07 & 0.54 & $0.73^{* *}$ & -0.10 \\
NGP & & & 1 & $0.71^{* *}$ & 0.009 & 0.37 & 0.15 & 0.36 & -0.25 \\
NGP & & & 1 & 0.33 & 0.52 & -0.29 & -0.20 & -0.24 \\
300M & & & & 1 & 0.49 & -0.41 & -0.06 & 0.04 \\
PROD & & & & & 1 & -0.48 & 0.01 & 0.05 \\
SPAD & & & & & & & & $0.66^{* *}$ & -0.15 \\
NDVI & & & & & & & & 1 & 0.02 \\
ST & & & & & & & & & 1 \\
\hline
\end{tabular}

${ }^{*}$ - significant at $1 \%$ probability; ${ }^{*}$ - significant at $5 \%$ probability.

ST 797 obtained values of NDVI statistically superior to the others. The NDVI values found corroborate with the results of [16] where, analyzing different times of data collection and position of the equipment in relation to the canopy of different soybean cultivars, indicated that the reading of this variable has a direct relation to the water regime in the plant. Thus, in addition to the phenological stage, collection time became a major factor for values above 0.7 , mainly in experiments conducted in the field, a situation similar to that occurred in this experiment.

The correlation analysis presented in Table 10 showed that, among the evaluated agronomic characteristics, there was a significant positive correlation between the numbers of grains per plant with number of pods per plant, demonstrating dependence between these variables. In this way, it is possible to infer that the greater number of pods per plant implies the number of grains per plant. In addition, the number of grains per pod also showed a significant correlation with the number of grains per plant, so it is plausible to consider that when the number of grains per plant is dependent on the number of grains per pod. The NDVI readings had a significant positive correlation with the number of pods per plant and SPAD index. This fact is the result of the evaluation time, because the readings were taken at the stage $\mathrm{R} 3$, characterized in [12] as the maximum accumulation of biomass of aerial part of the plant and, therefore, the chlorophyll content and also at the beginning of the formation of green beans. The productivity showed a negative correlation with the height of plants, indicating that the higher height influenced negatively the productivity. This statement corroborates the lodging values shown in Table 6. 


\section{Conclusions}

The difference in cycle of soybean cultivars occurs in the reproductive period. Early-cycle cultivars tend to use precipitation more efficiently if the rain occurs between the end of the vegetative stage and the beginning of the reproductive stage.

Soybeans cultivars with longer cycle are greater number of pods per plant. This effect doesn't have relation to grain yield, regardless of the level of investment in fertilization.

In cultivars with relative maturity groups (RMG) above 7.7, investment in fertilization leads to higher lodging of plants.

Medium investment in fertilization implies less lodging of plants soybeans. In this mode of cultivation, the chlorophyll content is higher due to the smaller size of the plants, however, there is a reduction of the productivity components, compromising the production of soybean grains.

Fertilizer investment increased significantly influences grain yield in contrasting cycles soybean cultivars.

\section{References}

[1] CONAB-Companhia Nacional de Abastecimento. (2017) Follow-Up of the Brazilian Grain Crop. http://www.conab.gov.br/conteudos.php? $\mathrm{a}=1252 \& \mathrm{t}=2$

[2] Ainsworth, E.A., Yendrek, C.R., Sitch, S., Collins, W.J. and Emberson, L.D. (2012) The Effects of Tropospheric Ozone on Net Primary Productivity and Implications for Climate Change. Annual Review of Plant Biology, 63, 637-661.

https://doi.org/10.1146/annurev-arplant-042110-103829

[3] Padua, G.P., França-Neto, J.B., Rossi, R.F. and Cândido, H.G. (2014) Agroclimatic Zoning of the State of Minas Gerais for the Production of High Quality Soybean Seeds. Journal of Seed Science, 36, 413-418.

https://doi.org/10.1590/2317-1545v36n41023

[4] Sediyama, C.S., Sediyama, T. and Sakiyama, N.S. (1989) Selection of Phenotypic Characters for Differentiation of Soybean Genotypes by Analysis of Main Components. Revista Ceres, 36, 330-335.

[5] Zanon, A.J., Streck, N.A., Rocha, T.S.M., Alberto, C.M., Bartz, A.C., Paula, G.M., Tomiozzo, R., Costa, L.C., Fensterseifer, C.A., Tagliapietra, E.L., Cardoso, A.P., Weber, O.S. and Bexaira, K.P. (2016) Effect of the Type of Growth on the Development of Modern Soybean Cultivars after the Onset of Flowering in Rio Grande do Sul. Bragantia, Campinas, 75, 446-458.

[6] $\mathrm{CiB}$-Conselho de Informaçõessobre Biotecnologia. Brazil Presents Growth in the Adoption of Transgenics (2017). http://cib.org.br/brasil-lidera-crescimento-mundial-da-adocao-de-transgenicos/

[7] Alliprandini, L.F., Abatti, C., Bertagnolli, P.F., Cavassim, J.E., Gabe, H.L., Kurek, A. and Steckling, C. (2009) Understanding Soybean Maturity Groups in Brazil: Environment, Cultivar Classification, and Stability. Crop Science, 49, 801-808. https://doi.org/10.2135/cropsci2008.07.0390

[8] Evans, L.T. and Fischer, R.A. (1999) Yield Potential: Its Definition, Measurement, and Significance. Crop Science, 39, 1544-1551. https://doi.org/10.2135/cropsci1999.3961544x 
[9] Ribeiro, A.B.M., Bruzi, A.T., Zuffo, A.M., Zambiazzi, E.V., Soares, I.O., Vilela, N.J.D., Pereira, J.L.A.R. and Moreira, S.G. (2017) Productive Performance of Soybean Cultivars Grown in Different Plant Densities. Ciência Rural, 47, e20160928. https://doi.org/10.1590/0103-8478cr20160928

[10] EMBRAPA (2013) National Soil Research Center. Brazilian System of Soil Classification. Rio de Janeiro, 2013, 353 p.

[11] Padilha, F.A., Resende, A.V., Moreira, S.G., Guimarães, L.J.M., Guimarães, P.E.O. and Oliveira, A.C. (2015) Productivity of Maize Hybrids under Two Levels of Technology in the Central Region of Minas Gerais. Revista Brasileira de Milho e Sorgo, 14, 207-218. https://doi.org/10.18512/1980-6477/rbms.v14n2p207-218

[12] Fehr, W.R., Caviness, C.E., Burmood, D.T. and Pennington, J.S. (1971) Stage of Development Descriptions for Soybeans, Glycine max (L.) Merril. Crop Science, 11, 929-931. https://doi.org/10.2135/cropsci1971.0011183X001100060051x

[13] Ferreira, D.F. (2011) Sisvar: Computational System of Statistical Analysis. Ciência e Agrotecnologia, 35, 1039-1042. https://doi.org/10.1590/S1413-70542011000600001

[14] Farias, J.R.B., Nepomuceno, A.L. and Neumaier, N. (2007) Ecophysiology of Soybean. Embrapa Soybean. Technical Circular (INFOTECA-E).

[15] Heatherly, L.G. and Smith, J.R. (2004) Effect of Soybean Stem Growth Habit on Height and Node Number after Beginning Bloom in the Midsouthern USA. Crop Science, 44, 1855-1859. https://doi.org/10.2135/cropsci2004.1855

[16] Crusiol, L.G.T., Carvalho, J.D.F.C., Sibaldelli, R.N.R., Neiverth, W., do Rio A., Ferreira, L.C. and Farias, J.R.B. (2017) NDVI Variation according to the Time of Measurement, Sampling Size, Positioning of Sensor and Water Regime in Different Soybean Cultivars. Precision Agriculture, 18, 470-490.

https://doi.org/10.1007/s11119-016-9465-6 